Бачишина Л. Д., старший викладач (Національний університет водного господарства та природокористування, м. Рівне)

\title{
ЕКОЛОГО-ЕКОНОМІЧНІ ІНСТРУМЕНТИ ЗАБЕЗПЕЧЕННЯ АДАПТАЦІЇ ЗЕРНОВИРОБНИЦТВА УКРАЇНИ ДО ЗМІНИ ПРИРОДНО-КЛІМАТИЧНИХ УМОВ
}

Виконано аналіз динаміки стану ґрунтів України. Встановлено, що розораність земель $є$ найвищою у світі, що порушує екологічну стійкість агроландшафтів і негативно впливає на зерновиробництво. Незадовільний стан ґрунтів та зміни клімату потребують трансформації зерновиробництва. Інструментами забезпечення адаптації зерновиробництва до нових природно-кліматичних умов $\epsilon$ впровадження екологічних технологій обробітку землі та захисту посівів, нових сортів зерна, надійне прогнозування основних показників зернової галузі.

Ключові слова: зміна клімату, трансформація зерновиробництва, ґрунти, родючість, деградація, органічне землеробство.

Постановка проблеми. Швидкий техногенний розвиток суспільства у XX-XXI століттях став причиною значного антропогенного впливу на навколишнє середовище. При збережені існуючих тенденцій людство ризикує перетнути межу самовідтворення природніх ресурсів, що може стати причиною глобальної екологічної катастрофи. Тому перехід до екологічної економіки та забезпечення відтворення ресурсного потенціалу планети $\epsilon$ найбільш актуальною задачею людства. Лише інтеграція економіки і природи забезпечує сталий розвиток суспільного виробництва і природних процесів [1].

Хоча за земельними ресурсами Україна $є$ однією з найбагатших світу і володіє найбільшими запасами чорнозему, проте недбалий спосіб ведення сільського господарства та занепад тваринництва стали причинами спаду агровиробництва та негативно вплинули на стан ґрунтів. Процес землеробського використання змінив структуру, склад і властивості ґрунту, які $є$ важливими для збереження родючості та успішного розвитку зерновиробництва, галузі, що $є$ основою світової продовольчої безпеки і важливим джерелом валютних надходжень до бюджету нашої країни.

Аналіз останніх досліджень і публікацій. Проблемам трансформації зерновиробництва в контексті змін клімату присвячено праці 
таких вітчизняних та зарубіжних вчених як: П.М.Грицюк, Л.М.Попитченко, Ю. О. Тараріко, В.М.Калініченко, В.П.Дмитренко, Т. В. Ільєнко, С. Г. Чорний, С. П. Позняк, М. І. Полупан. Проте недостатньо висвітленою залишається проблема впливу змін клімату та деградації ґрунтів на ефективність зернового господарства України. Зернове виробництво є дуже чутливим до змін кліматичних умов та родючості ґрунтів. Тому, проблема вивчення впливу природнокліматичних умов на зерновиробництво та адаптація його до нових кліматичних умов є надзвичайно актуальною сьогодні.

Виклад основного матеріалу. Майже 90\% земельного фонду України залучено до господарської діяльності. Площі сільськогосподарських угідь в різних адміністративних областях країни займають від 37 до 89\%. Розораність земель $є$ найвищою в світі. В західних областях вона складає в середньому 50\%, в центральних областях близько 70\%, і найбільш розорані земельні угіддя на сході України. Це порушує екологічно допустиме співвідношення площ ріллі, природних кормових угідь, лісових насаджень і негативно впливає на стійкість агроландшафту [2, С. 9]. Помітно знижуються запаси поживних форм фосфору і калію, численні негативні процеси спостерігаються на меліорованих землях. Головні причини незадовільного стану ґрунтового покриву - недооцінка реальної загрози, якою є деградація ґрунтів для теперішнього і наступних поколінь, відсутність дієвих механізмів виконання законів про охорону ґрунтів, незбалансоване і науково необґрунтоване землекористування, призупинення (фактично 3 1991 р.) дії державної і обласних програм охорони земельних ресурсів [3, с. 28].

Найбільші втрати гумусу відбулися у 60-80 рр. минулого сторіччя, у період інтенсифікації сільськогосподарського виробництва. Однією з причин масштабності втрат було збільшення площ просапних культур (цукрових буряків, кукурудзи тощо), оскільки надмірне розпушування землі призводить до посиленої мінералізації ґрунту і втрати гумусу. Щорічні втрати гумусу на той час складали 0,55-0,60 т/га. Одна з причин такої динаміки - різке зменшення обсягів застосування органічних добрив. Формування врожаю відбувалося лише за рахунок потенційної родючості ґрунту. Внаслідок чого деградаційні процеси набули величезних розмірів і ґрунти не встигають відновлювати свою природну родючість. Такий стан речей обумовлений тим, що тривалий час екстенсивне використання земельних угідь не компенсувалось відповідними заходами відтворення родючості ґрунту.

Методологічною основою системи відтворення і раціонального використання земель повинен стати науково обґрунтований систем- 
ний підхід. У кожному регіоні повинно бути своє, науково обґрунтоване співвідношення між полем, лісом, луками, болотами, водоймищами. Це дасть найвищий господарський ефект і збереже навколишнє середовище, тому що кожний вид ґрунту дозріває для обробітку в певний час і потребує різних форм обробітку, сортів добрив, гною, вапна тощо. Першочерговою задачею є зменшення площ розораних земель. 3 метою виконання цього завдання урядом України було прийнято ряд законодавчих документів, в яких говориться про необхідність формування збалансованого співвідношення між складовими агросистеми та забезпечення екологічної рівноваги території [4].

Нами розраховано економічний ефект від зменшення посівних площ під пшеницею, ячменем, кукурудзою та соняшником, оскільки саме ці культури $є$ важливим джерелом валютних надходжень до бюджету нашої держави та займають близько $60 \%$ у структурі посівних площ України. Як видно з таблиці, при зменшенні посівних площ під вищевказаними культурами на 10\%, втрати від експорту можуть становити 1837,83 млн \$. Проте, стан земельних ресурсів України на даний час $є$ близьким до критичного. Для збереження та відтворення родючості ґрунтів таки заходи є необхідними. Зменшення площі орних земель дозволить збільшити площі лісових насаджень та пасовищ, що проявиться у позитивному економічному, екологічному та соціальному аспектах. Збільшення площ пасовищ сприятиме розвитку кормової бази для тваринництва, яке $\epsilon$ споживачем продукції рослинницької галузі i, одночасно, забезпечить цю галузь органічними добривами. Підживлення посівних площ органічними добривами сприятиме нарощуванню гумусового шару ґрунту, підвищенню родючості ґрунту та підвищенню врожайності зернових культур. Економічним аспектом збільшення площ лісових насаджень $є$ покращення вологоутримуючої функції і зменшення еродованість земель. Акумулювання вуглецю лісовими екосистемами знижує негативні наслідки глобального потепління та парникового ефекту. Крім названих позитивних впливів лісові ландшафти та рекреаційні зони мають естетичну, духовну та культурну цінність для суспільства [5].

Таблиця

\section{Розрахунок економічного ефекту від зменшення}

орних земель

\begin{tabular}{|l|l|l|}
\hline \multicolumn{1}{|c|}{ Показники } & \multicolumn{1}{|c|}{ Зернові } & Соняшник \\
\hline Посівна площа, тис. га & 13340,0 & 5600 \\
\hline Валовий збір, млн т & 56,70 & 10,53 \\
\hline Світові ціни \$,т & 190,46 & 720 \\
\hline
\end{tabular}


продовження таблиці

\begin{tabular}{|l|l|l|}
\hline Урожайність, т/га & 4,25 & 1,88 \\
\hline Внутрішнє споживання & 20,00 & 0,50 \\
\hline Обсяг експорту, млн т & 36,7 & 10,0 \\
\hline Обсяг експорту, млн дол. & 6988,93 & 7220,16 \\
\hline Зменшення площі на 15\% & 12006,00 & 5040,00 \\
\hline Валовий збір млн т, після зменшення & 51,03 & 9,48 \\
\hline Обсяг експорту після зменшення, млн т & 31,03 & 8,98 \\
\hline $\begin{array}{l}\text { Обсяг експорту після зменшення площі, } \\
\text { млн дол. }\end{array}$ & 5909,12 & 6462,14 \\
\hline Втрати, млн дол. & 1079,81 & 758,02 \\
\hline
\end{tabular}

Ще одним засобом відтворення родючості грунтів $є$ дотримання корисних сівозмін. Науково обгрунтоване чергування культур у сівозміні сприяє покращенню водного режиму, раціональному використанню поживних речовин, досягненню позитивного балансу гумусу, що в цілому сприяє підвищенню врожаю. Зменшення кількості просапних культур у сівозміні також покращує структуру ґрунту і сприяє підвищенню вмісту гумусу в ньому. Особливо покращує структуроутворення ґрунту вирощування бобових і злакових багаторічних трав, а також суміші однорічних бобових і злакових трав. Крім того, оптимальне співвідношення у сівозміні рослин суцільної сівби і просапних стримує розвиток вітрової і водної ерозії. 3 метою відновлення родючості ґрунту та зменшення витрат на придбання добрив, вчені Миколаївської державної сільськогосподарської дослідної станції Інституту зрошуваного землеробства НААН України рекомендують 10-20\% посівної площі в степовій зоні України відвести під зернобобові культури. Це дозволить збільшити мобілізацію біологічного азоту. До того ж, бобові є хорошим попередником для озимих зернових і прибутковими культурами [6].

Економічно доцільним $€$ зменшення посівних площ - під зерновими і одночасне збільшення їх під зернобобовими у південно-східному регіоні, оскільки земельні угіддя цього регіону України $\epsilon$ найменш продуктивними на даний час. Нами розраховано економічний ефект такої від трансформації площ виробництва зернових та зернобобових у Одеській, Запорізькій та Миколаївській областях. Встановлено, що, при збільшенні площі посіву під зернобобовими та соєю на 15\% та одночасному зменшенні на таку саму величину площі посіву зернових можна отримати зростання ймовірного доходу від реалізації продукції в Запорізькій області - 3,85 млн грн, в Миколаївський - 2,04 млн грн, та Одеській - 3,34 млн грн. За умови зростання урожайності сої і зернобобо- 
вих, доходи зростатимуть ще більше.

Глобальні зміни природно-кліматичних умов та незадовільний стан ґрунтів в Україні потребують змін як у технологіях, так і у географії виробництва. Як показують наші дослідження, урожайність пшениці у східному регіоні у 2000-х практично не зростає. Потепління клімату дозволяє вирощувати кукурудзу на зерно та сою по всій території України. Зважаючи на це, ми пропонуємо наступний механізм трансформації структури посівних площ:

- у центральному регіоні зменшити посівні площі під соєю на 15\% (на 160,87 тис. га) і, відповідно, збільшити посівні площі пшениці на таку ж величину;

- у західному регіоні зменшити розмір посівної площі під соєю на 15\%, що становитиме 77,46 тис. га, і збільшити посівні площі під кукурудзою (на 77,46 тис. га).

- у східному регіоні зменшити посівні площі під пшеницею на 160,87 тис. га та посівні площі під кукурудзою на 77,46 тис. га, збільшити посівні площі під соєю на 77,46 +160,87 =238,33 тис. га.

У трансформації задіяні посівні площі пшениці, кукурудзи, та зернобобових культур, в тому числі сої. Оскільки ці культури дають позитивний ефект у сівозмінах та дозволяють відновити родючість ґрунтів. Запропоновані зміни дають змогу збільшити дохід від виробництва зернових та зернобобових культур на 1,40 млн грн (0,4\%). При обчисленнях використовувалась середня урожайність зернових та зернобобових культур у регіонах за період 2015-2017 рр. Якщо урожайність сої у східному регіоні зростатиме і складе 2,0 т/га, вигода від трансформації посівних площ під зернові та зернобобові культури зросте до 1,8 млн грн (0,5\%). Хоча економічний ефект в масштабах країни невеликий, при такій трансформації ми отримуємо помітний екологічний ефект - зменшення деградації ґрунту, відновлення гумусового шару, економія на азотних добривах, збільшення вмісту органічного вуглецю в ґрунті.

Ще одним із шляхів підвищення урожайності сільськогосподарських культур та відновлення родючості ґрунтів $€$ перехід до органічного землеробства, зокрема безполицевого, мінімального та нульового обробітку ґрунту. Перевагами цих технологій $є$ зменшення витрат на виробництво та позитивний вплив на стан ґрунту. Тривале застосування вказаних технологій забезпечує відновлення гумусового шару, сприяє збереженню вологи в ґрунті та зменшенню ерозійних процесів. Застосування малоінвазивних технологій дозволяє звести до мінімуму залежність агровиробни-цтва від погодно- 
кліматичних умов. Швидкість проведення посівної кампанії, економія людських ресурсів та палива, вологоутримуючий ефект та поступове підвищення родючості ґрунтів - позитивні аспекти цих технологій. Серед недоліків варто вказати значні витрати на придбання необхідної для виробництва техніки (тракторів, сівалок, оприскувачів), підвищення витрат на хімічні засоби захисту рослин та боротьбу 3 бур'янами. Спочатку дані технології застосовувались переважно у південно-східному регіоні, але, поступово все більше регіонів України переходять до їх використання.

3 метою визначення доцільності застосування технології no-till для вирощуванням зернових у західному регіоні України ми виконали розрахунок економічної ефективності виробництва озимої пшениці на прикладі ТзОВ сільськогосподарського підприємства «Імені Воловікова» с. Горбаків Гощанського району Рівненської області. Дослідження показали збільшення урожайності і валового виробництва у 1,4 рази, що дає збільшення доходу на 14,5 млн грн. Відвернений збиток від деградації темно-сірих опідзолених ґрунтів внаслідок середнього рівня ущільнення становить 201 грн/га; зменшення втрат гумусу - 0,2\% в рік; скорочення викидів парникових газів в атмосферу - 1,8 тон $\mathrm{CO}_{2}$ на га в рік, що складає $1 / 3$ щорічних глобальних викидів $\mathrm{CO}_{2}$ при спалюванні викопного палива.

Висновки. Визначено основні інструменти підвищення економічної ефективності та кліматичної адаптації зернової галузі: впровадження нових посухостійких сортів зерна, впровадження нових технологій обробітку та захисту посівів, використання високоточних та малоінвазивних агротехнологій вирощування зернових культур, дотримання корисних сівозмін, оптимізація структури посівів зернових культур з врахуванням витрат виробництва та продуктивності різних ділянок сільськогосподарських угідь. Важливим інструментом підвищення економічної ефективності та забезпечення екологічної стійкості зерновиробництва $є$ синергетична взаємодія рослинницької та тваринницької галузей.

1. Грабинський І. М. Сучасні економічні системи : навчальний посібник. Львів : Інтереко, 1997. 176 с. 2. Булигін С. Ю., Барвінський А. В., Ачасова А. 0. Оцінка і прогноз якості земель : навчальний посібник. Харків : Харківський національний аграрний університет, 2006. 262 с. 3. Крупеников И. А. Черноземы. Возникновение, совершенство, трагедия деградации, пути охраны и возрождения : монография. Кишинэу : Pontos, 2008. 288 с. 4. Наказ КМ України «Про стратегію сталого розвитку «Україна - 2020». URL: http://zakon.rada.gov.ua/laws/show/5/2015 (дата звернення : 09.10.2018). 5. Загвойська Л. Д., Шведюк Ю. В. Оцінювання екологоекономічної ефективності заходів з лісовідновлення. Науковий вісник НЛту 
України. 2015. Вип. 25.1. С. 123-130. 6. URL: http://www.ukrstat.gov.ua/ (дата звернення : 09.10.2018). 7. URL: http://agravery.com/uk/posts/show/zolotibobi-comu-roste-virobnictvo-gorohu-nutu-ta-socevici (дата звернення : 09.10.2018).

\section{REFERENCES :}

1. Hrabynskyi I. M. Suchasni ekonomichni systemy : navchalnyi posibnyk. Lviv : Intereko, 1997. 176 s. 2. Bulyhin S. Yu., Barvinskyi A. V., Achasova A. O. Otsinka i prohnoz yakosti zemel : navchalnyi posibnyk. Kharkiv : Kharkivskyi natsionalnyi ahrarnyi universytet, 2006. 262 s. 3. Krupenikov Y. A. Chernozemy. Vozniknoveniie, sovershenstvo, trahediia dehradatsyi, puti okhrany i vozrozhdeniia : monohrafiia. Kyshyneu : Pontos, 2008. 288 s. 4. Nakaz KM Ukrainy «Pro stratehiiu staloho rozvytku «Ukraina - 2020». URL: http://zakon.rada.gov.ua/laws/show/5/2015 (data zvernennia : 09.10.2018). 5. Zahvoiska L. D., Shvediuk Yu. V. Otsiniuvannia ekoloho-ekonomichnoi efektyvnosti zakhodiv z lisovidnovlennia. Naukovyi visnyk NLTU Ukrainy. 2015. Vyp. 25.1. S. 123-130. 6. URL: http://www.ukrstat.gov.ua/ (data zvernennia : 09.10.2018). 7. URL: http://agravery.com/uk/posts/show/zoloti-bobi-comuroste-virobnictvo-gorohu-nutu-ta-socevici (data zvernennia : 09.10.2018).

Рецензент: д.е.н., професор Грицюк П. М. (НУВГП)

Bachyshyna L. D., Senior Lecturer (National University of Water and Environmental Engineering, Rivne)

\section{ECOLOGICAL AND ECONOMIC INSTRUMENTS FOR ASSURING THE ADAPTATION OF UKRAINE CROP PRODUCTION TO THE NATURAL AND CLIMATIC CONDITIONS CHANGE}

The analysis of the dynamic of soil condition in Ukraine is done. It is defined that soils loss their fertility on the whole territory of the country at a rapid rate. The land plowing is the highest in the world. This results the environmental sustainability of agro-industrial plants and negatively influence on grain production. The poor soil conditions and climate change need the transformation of grain production. The basis for the transformation of the grain industry should be the measures program of sustainable land use. The program provides for the application of environmental technologies for the land cultivation and the crops protection, the use of new drought-resistant grain varieties, the restoration of eroded lands, observance of crop rotation, reliable prediction of the main indicators of grain industry, control and 
the government support. The important tool to improve the economic efficiency and environmental sustainability of grain production should be the synergistic interaction of the crop and livestock industries. Keywords: climate change, transformation of grain production, soil, fertility, degradation, organic farming.

Бачишина Л. Д., старший преподаватель (Национальный университет водного хозяйства и природопользования, г. Ровно)

ЭКОЛОГО-ЭКОНОМИЧЕСКИЕ ИНСТРУМЕНТЫ ОБЕСПЕЧЕНИЯ АДАПТАЦИИ ЗЕРНОПРОИЗВОДСТВА УКРАИНЫ К ИЗМЕНЕНИЯМ ПРИРОДНО-КЛИМАТИЧЕСКИХ УСЛОВИЙ

Выполнен анализ динамики состояния почв Украины. Установлено, что почвы быстрыми темпами теряют плодородие по всей территории страны. Распашка земель является самой высокой в мире, что нарушает экологическую устойчивость агроландшафтов и негативно влияет на производство зерна. Неудовлетворительное состояние почв и изменения климата требуют трансформации зернопроизводства. Основой трансформации отрасли зернопроизводства должна стать программа мероприятий устойчивого землепользования, которая предусматривает применение экологических технологий возделывания земли и защиты посевов, использование новых засухоустойчивых сортов зерна, восстановление эродированных земель, соблюдение севооборотов, надежное прогнозирование основных показателей зерновой отрасли, контроль и поддержку со стороны государства. Важным инструментом повышения экономической эффективности и экологической устойчивости зернопроизводства должно стать синергетическое взаимодействие растениеводческой и животноводческой отраслей. Ключевые слова: изменение климата, трансформация зернопроизводства, почвы, плодородие, деградация, органическое земледелие. 